Jurnal Ilmu Dan Teknologi Kesehatan

Vol 8, No 2, March 2021,

ISSN: 2338-9095 (Print)

ISSN: 2338-9109 (online)

\title{
Breathing And Stretching Exercises Affect The Decrease in The Intensity of Leg Cramp Pain
}

\author{
Achwan, Abdurahman B.B. Laksono \\ Poltekkes Kemenkes Jakarta III, Indonesia \\ Email:achwan_1973@yahoo.com
}

\section{Article history}

Posted, Feb 10th, 2021

Reviewed, Feb 13th, 2021

Received, March 15th, 2021

\begin{abstract}
Leg cramps are a common side effect of intradialysis CKD patients. Preventing intradialysis cramping pain can improve quality of life. Breathing and stretching exercises are nonpharmacological treatments for cramping pain. The purpose of this study was to prove the effect of breathing and stretching exercises on changes in the intensity of leg cramps in hemodialysis patients at the Haji Jakarta Hospital in 2018. This study was a quasiexperimental study with a two-group pre-post test research design. The sample was selected by purposive sampling, a sample of 34 patients. The intensity of muscle cramps was measured using the Numeric Rating Scale. The results of the analysis using the paired sample $T$-test. The results showed that the intervention group had a P-value $=0.01$ and the control group had a P-value $=0.055$, meaning that there was a difference in mean the intensity of cramping pain before and after breathing and stretching exercises was compared, so it was concluded that there was an effect of breathing and stretching exercises on the intensity of intradialysis leg cramps. Patients are advised to breathing and stretching exercises regularly, light exercise, eat and drink diet.
\end{abstract}

Keywords: breathing exercise; intradialysis cramps; stretching exercise

\begin{abstract}
ABSTRAK
Kram merupakan kontraksi otot yang tidak disadari dan mengakibatkan nyeri yang terjadi secara spontan. Kram tungkai kaki merupakan efek samping yang umum dialami pasien CKD intradialisis. Mencegah nyeri kram intradialisis dapat meningkatkan kualitas hidup. Latihan breathing dan stretching merupakan salah satu penanganan nyeri kram non farmakologi. Tujuan penelitian ini adalah untuk membuktikan adanya Pengaruh Latihan breathing dan stretching terhadap perubahan intensitas nyeri kram tungkai kaki pasien hemodialisis di RS haji Jakarta tahun 2018. Penelitian ini bersifat kuasi eksperimen dengan desain penelitian two group pre-post test, sampel dipilih secara purposive sampling dengan jumlah sampel 34 pasien. Intensitas nyeri kram otot diukur menggunakan Numeric Rating Scale. Perlakuan diberikan $2 \mathrm{x}$ seminggu dengan periode total perlakuan selama empat minggu dan pengukuran dilakukan 2x. Hasil analisa menggunakan paired sample T-test dengan tingkat kepercayaan 0,05 pada kelompok perlakuan dan kelompok kontrol sebelum
\end{abstract}


dan setelah latihan breathing dan strectching didapatkan kelompok perlakuan memiliki $\mathrm{P}$ value $=0,01$ dan kelompok kontrol memiliki $\mathrm{P}$ value $=0,055$, artinya terdapat perbedaan rerata intensitas nyeri kram sebelum dan setelah diberi latihan breathing dan stretching dibanding kontrol sehingga disimpulkan terdapat pengaruh latihan breathing dan stretching terhadap intensitas kram tungkai kaki intradialisis. Disarankan pasien latihan breathing dan stretching rutin, olahraga ringan serta diet makan dan minum.

Kata Kunci: kram intradialisis; latihan breathing; latihan stretching.

\section{INTRODUCTION}

Muscle cramps in the legs and hands are a common side effect experienced by Chronic Kidney Disease (CKD) patients undergoing hemodialysis (Baradero, M., et al., 2009). Preventing muscle cramp pain due to hemodialysis can improve the patient's quality of life and reduce depression, anxiety, and death risk. According to Desita (2010) in Batur (2013), the quality of life of chronic kidney failure patients is influenced by two factors, namely sociodemography and medical condition. Sociodemographic factors consist of gender, age, ethnicity, education, occupation, and marital status. In contrast, medical condition factors consist of long undergoing hemodialysis, stage of the disease, and medical management. Stretching of passive muscles at the end of hemodialysis showed a significant decrease in intensity, duration, and muscle cramps frequency in 2 hours after hemodialysis (Elavally $\mathrm{S}$ et al., 2017).

Research proves that low-intensity Intra dialysis stretching exercises become effective in reducing muscle cramps among patients undergoing hemodialysis (Tamilnadu Dr. MGRamachandran (MGR) 2016). Treatment of Intra dialysis CKD patient muscle cramps is often done using medications that will worsen the patient's condition (Bandero, M. et al., 2009). In contrast, non-pharmacological treatment of cramps such as breathing exercises, stretching, relaxation, heat therapy, massage, nerve stimulation, physical exercise, and others have not been widely researched.

Observations and interviews with patients undergoing hemodialysis at the Hemodialysis Unit of RS Haji Jakarta are known that the number of CKD patients who experience muscle cramp pain often complains of legs. The cause of cramping itself is not yet known for sure. However, one hypothesis is that the cause of cramping comes from the spinal (central origin), namely the hyperexcitability of motor neurons. Other hypotheses say that the motor nerve's spontaneous dismissal or abnormal excitatory from the terminal 
branch of motor axons (peripheral origin). Maximum muscle contractions volunter will not cause pain. However, pain can occur when electrical stimulation of the muscles or motor nerve exceeds the muscle tension limit when volunter contraction occurs. (Fields, 1960).

Cramping lasts an average of 10 minutes and is characterized by a prelude of about 3 minutes and a cramping process for 7 minutes; they occur in patients with increased muscle tone stimulation at the beginning. These cramps are also experienced during high ultrafiltration levels until the end of dialysis treatment and during the night between dialysis treatments. Hypothesized that hyponatremia, decreased plasma volume, and concomitant cellular overhydration is possible causes. (Alex O. Roca et al., 1992). Complications of cramping were observed in $24 \%-86 \%$ of cases during the first years of dialysis therapy. However, data showed that only $2 \%$ of patients suffered from cramps after having $\geq$ two hemodialysis sessions in a week. (Jesus, A.C., 2009). The pain intensity measurement in this study used pain measurement with Numeric Rating Scale (NRS) with the interpretation of painless (0), mild pain (1 - 3), moderate pain (4 -
6), and severe pain (7 - 10) (Castarlenas, 2017).

Stretching exercises are a form of exercise done to stretch muscles to be more relaxed (Macdonald, 1992).

Stretching is a technique of stretching on soft tissues with specific techniques to lower muscle tension physiologically so that the muscles become relaxed and increase the area of joint motion. The benefit of muscle stretching exercises is to increase joint wiggle room progressively. Besides, it can improve physical fitness. According to Tamilnadu research Dr. MGR (2016), low-intensity intradialysis stretching exercises effectively reduce muscle cramps among patients undergoing hemodialysis. The study was reinforced by Elavally S et al. (2017) research that passive muscle stretching at the end of hemodialysis showed a significant decrease in intensity, duration, and frequency of muscle cramps 2 hours after hemodialysis.

Breathing exercises are a natural healing technique and are part of a holistic selfcare strategy to address complaints such as fatigue, pain, sleep disorders, stress, and anxiety. Physiologically, breathing exercises will stimulate the parasympathetic nervous system. It 
increases endorphin production, lowering heart rate, increasing lung expansion to develop to its maximum, and relaxing muscles (Stanley, R., 2016).

Research conducted by Sriati (2014) said a combined effect of the relaxation of deep breath and progressive muscles on Intra dialysis complications such as systolic blood pressure, diastolic blood pressure, headaches, muscle cramps, nausea, and vomiting are shown with a p-value of 0.000 . This breathing exercise can be used as an exercise during hemodialysis or Intra dialysis exercise (Sriati et al., 2014).

This study intends to determine the effect of breathing and stretching exercises on the Intensity of Leg Cramp Pain of Intra dialysis Patients. Specifically in this study is the conduct of self-stretching exercises or assisted by nurses or using existing equipment such as blankets that were not conducted in previous research conducted by Sriati (2014),

\section{METHOD}

This research is a quasi-experimental research with pre and post-test two-group designs. This study's variables are breathing, stretching exercises as independent variables, and the intensity of leg cramp pain as dependent variables. The study used one treatment group and one control group. In the treatment group, they were given exercises in the form of stretching and breathing. Stretching of the legs includes hip flexors, hamstrings, dorso, and plantar flexors with a 5-minute workout dose of 4 sets (15 reps per 4 sets with a break of 15 seconds per set). While breathing exercises are performed both in the intervention group and control group with a comfortable position and relax, they sit and lie down. Breathing exercises, breathe and exhale through the mouth with a pause of 1 to 2 seconds as much as felt comfortable. In the intervention and control groups, both received treatment and medical measures according to hospital procedures, namely $\mathrm{NaCl}$ fluid during Intra dialysis cramp pain.

This research was conducted in the Hemodialysis Unit of Rs Haji Jakarta in 2018. The population of this study is all Hemodialysis Patients in Haji Hospital Jakarta. The samples that met the inclusion and exclusion criteria numbered 34 patients divided into two groups, and each group consisted of 17 patients. Inclusion criteria:

a. CKD patients undergoing Hemodialysis

b. Routinely perform Hemodialysis

c. Respondents are aware and can communicate actively 
d. Respondents are willing to sign a research approval sheet (informed consent)

while the exclusion criteria

a. Not willing to follow this research.

b. Respondents who resigned before the implementation of the exercise was completed

c. and experiencing deteriorating conditions/decreased awareness.

d. Are following research elsewhere.

The sampling technique used is a purposive sampling (Sugiyono, 2013). The measuring instrument used is a Numeric Rating Scale checklist and questionnaire. The questionnaire question has been tested for validity and has a reliability of 0.604 (alpha Cronbach > 0.6). Data analysis is done with univariate or bivariate with Paired T-test. Before the research was conducted, researchers conducted explanations before the study, and respondents filled out informed consent to maintain respondents' confidentiality. This research has been approved by the Health Research Ethics Commission of the Jakarta Ministry of Health III No. KEPKPKKJ3/241/V/2018.

\section{RESULTS AND DISCUSSION}

Characteristics of respondents based on age in the treatment and control group can be seen in Table 1 below:

Table 1. Distribution of respondents' frequency by age at treatment and control groups

\begin{tabular}{|c|c|c|c|c|c|}
\hline Group & Variabel & Mean & SD & Min & Max \\
\hline Treatment & \multirow{2}{*}{ Age } & 49 & 11,3 & 24 & 67 \\
\hline Control & & 47.6 & 12,8 & 28 & 70 \\
\hline
\end{tabular}

The table above shows that the average age of patients as respondents from the univariate data analysis obtained the results that hemodialysis patients in Haji Hospital's average adult age of 49 years with the standard deviation is \pm 11 .3. In contrast, the youngest age is 24 years and the oldest 67 years in the treatment group while in the average control group aged
47.6 years with the standard deviation is \pm 12.8 whereas the youngest is 28 years old. And the most 70 years old. According to the Australian Institute of Health and Welfare in Laily I. et al. (2014), age and gender are among the predisposing factors for the occurrence of CKD. According to Więcek A. Gojowy D. (2017), CKD is one of the diseases characterized by increasing 
incidence with age, as evidenced by the incidence of CKD prevalence in the
United States, which is from $11 \%$ to $30 \%$ occurs in the elderly population.

Table 2. Frequency distribution of respondent characteristics

\begin{tabular}{lcccc}
\hline $\begin{array}{c}\text { Respondent } \\
\text { characteristics }\end{array}$ & \multicolumn{2}{c}{ Control } & Group & Treatment \\
\hline Gender & $\mathrm{n}$ & $\%$ & $\mathrm{~N}$ & $\%$ \\
Female & 8 & 47.1 & 9 & 52.9 \\
Male & 9 & 52.9 & 8 & 47.1 \\
\hline Disease history & 10 & 58.8 & 6 & 35.1 \\
Hypertension & 6 & 35.2 & 7 & 41.1 \\
Diabetes Mellitus & 1 & 6 & 2 & 11.8 \\
Indigestion & 17 & 41 & 1 & 6 \\
Kidney Tumors & & & 1 & 6 \\
Kidney Stones & 1 & 6 & & \\
\hline Education & 8 & 47 & 2 & 11.8 \\
Basic School & 2 & 12 & 1 & 6 \\
Junior school & 4 & 23.5 & 6 & 35.2 \\
High school & 1 & 6 & 1 & 6 \\
Diploma & 17 & 100 & 4 & 41 \\
Scholars & & & 3 & 12 \\
Master & 4 & 23.5 & & \\
Civil Servants & 6 & 35.3 & 4 & 23.5 \\
Private & 4 & 23.5 & 4 & 23.5 \\
Self-employed & 17 & 100 & 2 & 11.8 \\
Housewises & & & 7 & 41.2 \\
\hline Occupation & 6 & 35.3 & & \\
One year & 7 & 41.2 & 7 & 41.2 \\
Two years & 0 & 0 & 4 & 23.5 \\
Three years & 17 & 100 & 6 & 35.3 \\
>3 years & & & 0 & 0 \\
\hline & & & & \\
\hline & & & & \\
\hline
\end{tabular}

Table 2 above shows that the distribution of respondents' frequency based on gender between male and female is not much different in both treatment and control groups. The treatment group showed eight males $(47.1 \%)$ and nine females (52.9\%), while in the male control group, as many as nine people $(47.1 \%)$ and eight females (52.9\%). According to Laily I. et al.
(2014), The most gender predisposition factor is male by $59 \%$. It is related to strenuous activity performed by $68 \%$ of other physical activities.

Gender frequency distribution data in this study stated that between males and females is not much different because it is related to dietary compliance of fluids consumed that cause fluid withdrawal 
when hemodialysis is also high so that the risk of cramping pain. (Cicielia E. R., 2019). History of disease in the treatment group dominated by Hypertension disease six people (35\%) and Diabetes Mellitus 7 people $(41.1 \%)$ while the control group was dominated by Hypertension disease ten people (58.8\%) and Diabetes Mellitus 6 people (35.2\%). Indonesian Renal Registry (IRR) in 2014 also stated that the most etiology sequence of $\mathrm{CKD}$ is hypertension (37\%), diabetes mellitus (27\%), and glomerulonephritis (10\%). Frequency distribution by occupation dominated by IRT 7 people $(41.2 \%)$ treatment group and the self-employed six people $(35.3 \%)$ control group. The cause of the high number of housewives and self-employed in the frequency distribution data in this study was because, after CKD, predominantly female patients resigned from their jobs, and the focus in the household was for male patients to resign from the workplace and entrepreneurship to continue their lives.

Frequency distribution based on education is dominated by high school-educated patients, as many as six people (35\%) in the treatment group and eight people (47\%) control group. While frequency distribution based on the length of undergoing hemodialysis therapy from all respondents is $\leq$ three years as $17(100 \%)$ treatment and control groups. According to Cicielia E. R. research (2019), dietary adherence in CKD patients is meaningfully influenced by the knowledge and duration of hemodialysis. Lack of adherence to the diet, especially the diet of drinking consumption, leads to a considerable weight gain. The withdrawal of fluid hemodialysis time is also a lot that causes frequent cramp pain.

Measurement of the intensity of cramp pain is carried out both before and after the intervention. The treatment group was given interventions in the form of breathing and stretching exercises, while the control group was given interventions in the form of breathing exercises. The results of measuring the intensity of cramp pain can be seen in the following table 3 : 
Table 3. Results of Measurement of Cramp Pain Intensity Before And After Breathing And Stretching Exercises In Treatment And Control Group.

\begin{tabular}{clccccc}
\hline Group & \multicolumn{1}{c}{ Data } & Mean & SD & Min & Max & CI \\
\hline \multirow{2}{*}{ Treatment } & Pre-Test & 5,59 & 2,347 & 3 & 9 & $4,38-6,79$ \\
\cline { 2 - 7 } & Post-Test & 3,12 & 1,616 & 1 & 6 & $2,29-3,95$ \\
\hline \multirow{2}{*}{ Control } & Pre-Test & 5,41 & 1,698 & 3 & 9 & $4,54-6,28$ \\
\cline { 2 - 7 } & Post-Test & 5,06 & 2,045 & 1 & 9 & $4,01-6,11$ \\
\hline
\end{tabular}

The pre-test results found that the average pain in the treatment group was 5.59 and the control group was 5.41. The interpretation of the Numeric Rating Scale (NRS) measurement results is painless $(0)$, mild pain (1 - 3), moderate pain (4 - 6), and severe pain $(7$ - 10) (Castarlenas, 2017). The minimum pain value is 3.00 , which means mild pain, and the maximum pain value is 9.00 , which means severe pain. With an estimated interval of $95 \%$, it is believed that the average pain value of the treatment group sample is 4.38 to 6.79 while the control group is 4.54 to 6.28 . It indicates that both the treatment and control groups generally experience mild to severe cramping pain during the pre- test. In line with Elavally $\mathrm{S}$ research et al. (2017), muscle cramps are a common side effect in patients with chronic intra dialysis kidney disease. Preventing muscle cramps due to hemodialysis can improve the patient's quality of life and reduce depression, anxiety, and risk of death.

Bivariate analysis was conducted to analyze the effect of breathing and stretching exercises on the decrease in cramp pain intensity before and after intervention in the treatment and control group. Shapiro-Wilk test results obtained p-value > $>(0.05)$ in each data group and declared normal distribution data so that the following analysis using paired sample T-test.

Table 4. Test Results paired sample T Before And After Intervention In Both Groups

\begin{tabular}{|c|c|c|c|c|c|c|c|}
\hline \multirow{2}{*}{ Group } & \multirow{2}{*}{ Mean } & \multirow{2}{*}{ SD } & \multirow{2}{*}{$\mathbf{T}$} & \multirow{2}{*}{$\mathbf{P}$} & \multicolumn{2}{|c|}{ CI } & \multirow{2}{*}{ Explanation } \\
\hline & & & & & Min & Maks & \\
\hline $\begin{array}{l}\text { Treatment Pre- } \\
\text { Post test }\end{array}$ & 2,47 & 2,375 & 4,289 & 0,01 & 1,250 & 3,6892 & $\begin{array}{c}\text { there are an } \\
\text { average differences }\end{array}$ \\
\hline $\begin{array}{l}\text { Control } \\
\text { Pre-Post test }\end{array}$ & 0,353 & 0,702 & 2,073 & 0,055 & 0,008 & 0,714 & $\begin{array}{l}\text { No significant } \\
\text { Difference }\end{array}$ \\
\hline
\end{tabular}

Changes in the difference in the average intensity of cramp pain in the treatment group before and after breathing and stretching exercises can be seen in table 4.
The paired sample T-test results in the treatment group, the p-value 0.01. It concluded that there is an average difference in cramp pain intensity between 
before and after the intervention. It suggests that breathing and stretching exercise interventions can lower cramping pain. The Control Group trained in breathing showed an average difference in cramp pain intensity before and after the intervention. Table 4 above is 0.353 with a standard deviation of 0.702 , and t calculate 2.073. The paired sample T-test results in the p-value control group of 0.055 (p-value $>0.05)$ can be concluded if there is no significant difference in the average intensity of cramp pain between before and after being given breathing exercise intervention. It was concluded that the treatment group had a significant influence before and after breathing and stretching exercises compared to the control group. It is in line with Dr. MGR's Tamilnadu research (2016) that low-intensity Intra dialysis stretching exercises effectively reduce muscle cramps among patients undergoing hemodialysis. The study was reinforced by Elavally S et al., (2017) research that passive muscle stretching at the end of hemodialysis showed a significant decrease in intensity, duration, and frequency of muscle cramps 2 hours after hemodialysis and Sriati et al. (2014) that Breathing exercise can be used as an exercise during hemodialysis or intradialytic to reduce muscle pain and relaxation. This study proves that interventions in the form of stretching and breathing exercises can decrease leg cramp pain intensity, especially in intradialysis patients, so that this exercise can be given to hemodialysis patients to prevent the occurrence of muscle cramp pain. Reduced muscle cramp pain can improve the patient's quality of life and reduce depression, anxiety, and death risk.

\section{CONCLUSION}

The provision of breathing and stretching exercises in intra dialysis patients can reduce lower limb cramp pain intensity. There is an influence of breathing and stretching exercises on the decrease in lower limb cramps intensity in hemodialysis patients at Haji Hospital Jakarta in 2018. The advice that the author can convey so that intraanalysis patients do not experience cramp pain is that patients routinely perform breathing and stretching exercises to deal with intra dialysis cramp pain and light exercise. Also, for the patient to always maintain drinking consumption that can cause excessive fluid build up in the body resulting in fluid withdrawal through high hemodialysis, this often causes intradialysis cramp pain. 


\section{ACKNOWLEDGEMENT}

The author thanked all parties involved in this study: Director of Poltekkes Kemenkes Jakarta III as a funder, The Ethics Commission of The Jakarta Health Polytechnic Ministry III, and the Director of Haji Hospital Jakarta, who has provided the opportunity to conduct research as well as nurses and patients of the Hemodialysis section who are very helpful in the implementation of this research.

\section{REFERENCES}

Alex O. Roca, et al. (1992). Dialysis Leg Cramps Efficacy of Quinine Versus Vitamin E, ASAIO Journal 1992

Badan Penelitian dan Pengembangan Kesehatan. (2013). Riset Kesehatan Dasar Tahun 2013. Jakarta: Kementerian Kesehatan RI

Baradero, M. et.al. (2009). Klien Gangguan Ginjal, Seri Asuhan Keperawatan. Jakarta: EGC.

Blum, A. S., \& Rutkove, S. B. (2007). The Clinical Neurophysiology Primer. New Jersey: Humana Press Inc.

Breivik, H. (2017). Patients' subjective acute pain rating scales (VAS, NRS) are acceptable; more elaborate evaluations needed for chronic pain, especially in the elderly and demented patients. Scandinavian Journal of Pain, 1-2.

Cicielia E. R. (2019). Pengaruh Kepatuhan Diet Pada Pasien Gagal Ginjal Kronis di Unit Hemodialisa Rumah Sakit Sumber Waras. Jurnal Ilmiah Kesehatan, 11 (1).
Dahle, L., \& Berg, G. (1995). The Effect Oral Magnesium substitution on pregnancy-induced leg cramps. American Journal of Obstetrics and Gynecology, 173, 175-80.

Dona Fitri Annisa D., F., \& Ifdil. (2016) Konsep Kecemasan (Anxiety) pada Lanjut Usia (Lansia). Konselor, 5(2) http://ejournal.unp.ac.id/index.php/k onselor.

Elavally S et al. (2017). Effect of prophylactic intra-dialytic stretching exercises (IDSE) on muscle cramps among patients undergoing hemodialysis: a single-blind experimental study. $J$ Health, 7(1):50-62.

Fields, A. (1960). Leg Cramp. In A. Fields, Etiology and Pathophysiology (p. 204). Los Angeles: Califonia Medicine.

Hastono, Sutanto P. (2016). Analisis Data Pada Bidang Kesehatan. Depok: PT. Raja Grafindo Persada.

Herlina, Santi. (2013). Pengaruh Progressive Muscle Relaxation (PMR) Terhadap Tingkat Fatigue Pada Pasien Gagal Ginjal Kronis Yang Menjalani Hemodialisa di Rumah Sakit Pusat Angkatan Darat, Gatot Soebroto. Jakarta: Tesis UI.

Jangkup Jhoni Y. K, dkk. (2015). Tingkat Kecemasan pada Pasien Penyakit Ginjal Kronik (PGK) yang Menjalani Hemodialisis di Blu RSUP Prof. Dr. R. D. Kandou Manado. Jurnal eClinic (eCl), 3(1)

Jesus, A.C., Oliveira, H.A., Paixão, M.O., Fraga, T.P., Barreto, F.J. \&Valença, M.M. (2009). Clinical description of hemodialysis headache in end-stage 
renal disease patients. Arq Neuropsiquiatr, 7(4), 978-981

Laily I. et al. (2014). Prevalensi Faktor Risiko Gagal Ginjal Kronik. UNMUH Ponorogo.

Lestari A. \& Rukmi D.K. (2017). Gambaran Tingkat Kecemasan Pasien Gagal Ginjal Kronis yang Menjalani Hemodialisis Berdasarkan Kuesioner Zung SelfRating Anxiety Scale di RSUD Wates Tahun 2017.

Macdonald, R. (1992). Therapeutic Exercise: Foundations and Techniques. 2nd Edn. British journal of sports medicine, 26. https://doi.org/10.1136/bjsm.26.1.69.

Minetto, M. A. (2012). Origin and Development of Muscle Cramp. Exercise and Sport Sciences Reviews Sports Medicine, 3.

Nelson, Arnold G. (2007). Stretching Anatomy. United States of America: Human Kinetics.

Novita Nipa, N. (2017). Pengaruh Latihan Relaksasi Napas Dalam Terhadap Perubahan Skor Kecemasan Pasien Penyakit Ginjal Kronik yang Menjalani Hemodialisis di Rumah Sakit Pendidikan Universitas Hasanuddin, Makassar.
Sriati, dkk. (2014). pengaruh gabungan relaksasi napas dalam dan otot progresif terhadap komplikasi intradialisis di unit hemodialisis rsup $d r$. soeradji tirtonegoro klaten.

Stanley, $\mathrm{R}$ of a holistic breathing technique., Leither, T.W., \& Sindelir, C. (2011). Benefits in patients on hemodialysis. Nephrology Nursing Journal, 38(2), 149-153. Sherwood L. Fisiologi Manusia dari Sel ke Sistem. 2016.

Sugiyono. 2013. Metode Penelitian Manajemen. Bandung : Alfabeta.

Sugiyono. 2013. Metode Penelitian Kuantitatif Kualitatif dan $R \& D$. Bandung : Alfabeta.

Tamilnadu. (2016). The Effect of Intradialytic Low-Intensity Stretching Exercise on Muscle Cramps Among Patients Undergoing Haemodialysis in Selected Hospital at Kallakurichi. Disertation Medical University, Chennai.

Wibowo, Adik. (2014). Metodologi Penelitian Praktis Bidang Kesehatan. Jakarta : PT RajaGrafindo Persada.

Więcek A. Gojowy D. (2017). Chronic Kidney disease and ageing. $J G G$, 65(4): 299-302 